ECOLOGICA, Vol. 28, No 103 (2021), 435-442

https://doi.org/10.18485/ecologica.2021.28.103.14

Оригинални научни рад

УДК: 338.48-6:502/504] :[616.98:578.834

\title{
Екотуризам после пандемије COVID-19: могуће детерминанте развоја
}

\section{Ecotourism after the COVID-19 pandemic: possible development determinants}

\author{
др Горан Дашић", др Ана Ануфрријев², др Драган Милачић \\ 1Висока школа модерног бизниса, Теразије 27, Београд, Србија / \\ Modern Business School, Terazije 27, Belgrade, Serbia \\ 2,3Висока пословна Школа струковних студија „Чачак“, Градски парк 2, Земун, Србија / \\ Business School Čačak, Higher Education Institution for Applied Studies, Gradski park 2, Zemun, Serbia \\ *Аутор за преписку / Corresponding author
}

Рад примљен / Received: 09.12.2020, Рад прихваћен / Accepted: 15.08.2021.

\begin{abstract}
Сажетак: Криза проузрокована пандемијом COVID-19 тешко да може да се упореди са било којом претходном кризом. Пандемија је учинила да се свет који познајемо преко ноћи промени. Примарни циљ на глобалном нивоу постала је борба за очување живота и здравља људи. Последице те борбе осетили су и привреда и становништво широм света. Изузетак није био ни туризам. На самом почетку пандемије Светска туристичка организација Уједињених нација је објавила процену да се у међународном туризму очекује оад промета у 2020. години између 60 до $80 \%$ у односу на 2019. годину. Подаци са почетка 2021. године указују да су, на жалост, били у праву. Сви туристички сектори су подједнако погођени, а међу њима и еко туризам. Међутим, забрана кретања становништва, односно путовања као и и смањење привредних активности позитивно утичу на очување биодиверзитета и смањење загађења, што у контексту екотуризма може и треба да представља окосницу његовог будућег развоја. Отежавајућа околност је то што још увек не знамо на који начун ће се ово окончати и какве ће све послеице остваити на друштво. Правити одређене пројекције и планове за постковид период још увек је незахвално, али оно што се већ сада може утврдити јесу одређени принципи на којима би се темељио будући развој екотуризма.
\end{abstract}

Кључне речи: Пандемија, COVID-19, екотуризам, туризам, криза.

\begin{abstract}
The crisis caused by the COVID-19 pandemic can hardly be compared to any previous crisis. The pandemic has changed the world we know overnight. The primary goal on a global level has become the fight to preserve human life and health. The consequences of that struggle were felt by the economy and the population around the world. Tourism was no exception. At the very beginning of the pandemic, the United Nations World Tourism Organization published an estimate that international tourism is expected to have between 60 and $80 \%$ turnover in 2020 compared to 2019. Data from the beginning of 2021 indicate that, unfortunately, they were right. All tourism sectors are equally affected, including ecotourism. However, the movement restriction, ie travel, as well as the reduction of economic activities have a positive effect on the conservation of biodiversity and the reduction of pollution, which in the context of ecotourism can and should be the backbone of its future development. The aggravating circumstance is that we still do not know in what way this will end and what consequences it will have on society. Making certain projections and plans for the postcovid period is still ungrateful, but what can already be determined are certain principles on which the future development of ecotourism would be based.
\end{abstract}

Keywords: Pandemic, COVID-19, eco-turism, tourism, crisis.

${ }^{1}$ orcid.org/0000-0002-9001-7468, e-mail: goran.dasic@mbs.edu.rs

2orcid.org/0000-0001-5476-440X, e-mail: anufrijevana@hotmail.com

${ }^{3}$ orcid.org/0000-0002-3380-1678, e-mail: milacicdragan@gmail.com 


\section{УВОД / INTRODUCTION}

У многим развијеним земаљама и земаљама у развоју туризам представља једну од водећих грана привреде. Према подацима Светског савета за путовања и туризам, сектор туризма је у светском бруто домаћем производу 2019. године учествовао са 10,4\%, а сваки десети запослени у свету радно је био ангажован управо у туризму. У складу са вишегодишњим трендом раста, предвиђања за 2020. годину била су крајње оптимистичка. Међутим, ескалација пандемије COVID19, крајем 2019. и почетком 2020. године, распршила је наде и очековања у наставак раста туристичког сектора као мехур од сапунице. Ограничења кретања и забране путовања, затварање лука и аеродрома, карантин и мере социјалног дистанце и закључавања учинили су да индустрије туризма и угоститељства у 2020. години уместо очекиваног раста забележе пад који је према подацима Светске туристичке организације био скоро $80 \%$ у односу на претходну годину. У том погледу изузетак није био ни екотуризам, форма туризма која је настала као потреба људи да путују на начин који не девастира животну средину. Фокус у овом раду није само на утицају који пандемија COVID-19 има на екотуризам, већ и на идентификовацији фрактора који ће да детерминишу развој екотуризма у постковид периоду. У раду настаји да се укаже на фракторе који ће да учине отколон од свега оного што је било негативно у туризму (прекомерност, неодрживост и сл) и истовремено омогуће трансформацију у правцу одрживог развоја и унапређења екотуризма.

\section{1. МАТЕРИЈАЛИ И МЕТОДОЛОГИЈА / MATERIALS AND METHODS}

У складу са дефинисаним циљем и сврхом рада, током истраживања су коришћене различите методе, укључујући методе и инструменте директне и секундарне анализе. Стога, методо- лошки приступ био је подељен у две главне фразе којима је заокружено истраживање везана за то на који начин криза изазвана пандемијом COVID19 утиче на туристички сектор, посебно на сектор екотуризма и могућности за будући развој. Поменуте две фразе представљале су прикупљање доступних података о промету туристичког сектора глобално и у Републици Србији пре кризе и податке које се односе на туристички промет у кризном периоду. Коришћењу су подаци кредибилних домаћих и страних институција. У другој фрази консултована је најновија релевантна светска литература из предметне области како би се стекла дубинска перцепције главних питања о томе како ова пандемијска криза утиче на туристички сектор и на који начин се она може искористити за посткризни развој екотуризма.

\section{2. РЕЗУЛТАТИ И ДИСКУСИЈА / RESULTS AND DISCUSSION}

Туризам има велики потенцијал да на одржив начин убрза економски раст. Кроз интегрисане политике, туризам може да омогући запошљавање, трајни економски и друштвени раст, смањење сиромаштва, заштиту животне средине. (Khan, et al., 2020). Туризам може да представља иницијалну капсулу и за развој и отварање нових радних места у нетуристичким делатностима као што су: пољопривреда, грађевинарство, производња, малопродаја и трговина. Развој туризма повлачи за собом доступност јавних добара и развој инфраструктуре за локално становништво, што у крајњој инстанци имплицира повећањем прихода.

Према подацима Светске туристичке органиоације туризам је у периоду 2015-2019. година бележио константан просечан годишњи раст од скоро 5\%, тачније 4,94\%. Број ноћења страних туриста, као и раст у односу на претходну годину за период 2015-2019. година приказани су у Табели 1.

Табела 1 - Број ноћења страних туриста у 2015-2019. година и годищње стопе раста /

Table 1 - Number of overnight stays of foreign tourists 2015-2019 and annual growth rates

\begin{tabular}{|l|c|c|c|c|c|}
\hline Година & 2015 & 2016 & 2017 & 2018 & 2019 \\
\hline Раст у односу на претходну годину & $+4,8 \%$ & $+3,9 \%$ & $+7 \%$ & $+5 \%$ & $+4 \%$ \\
\hline Број туриста (у милијардама) & 1,186 & 1,235 & 1,326 & 1.4 & 1,460 \\
\hline
\end{tabular}

Извор / Source: (UNWTO, 2016, 2017, 2018, 2019, 2020)

Пројекције за 2020. године предвиђале су раст између $3 \%$ и 4\% у односу на 2019 годину, чиме би број туриста премашио 1.5 милијарди. (UNWTO - World Tourism Barometer, 2020). Мeђyтим, проглашење пандемије COVID-19, односно увођење мера којима би се контролисало и минимизирало ширење пандемије, као што су забране путовања, затворање граница или увођење карантина за последицу су имале драстично смањење броја домаћих и страних туриста, укидање 
ваздушног саобраћаја, крстарења, јавног превоза, затварање хотела, пансиона, кафића и ресторана и др. што је значило драстичан пад промета туристичког сектора.

Прве прогнозе из априла 2020. године предвиђале су пад туристичког промета у 2020. години за 60 до 80\%. (UNWTO Reports, 2020). Први подаци показују да је туристички сектор 2020. године претрпео највећу кризу. Број ноћења иностраних туриста у 2020. години био је за $74 \%$ одсто мањи у односу на претходну годину. (UNWTO - World Tourism Barometer, 2021). Подаци за јануар 2021, године указују на још драстичнији пад јер је број долазак туриста у јануару 2021 за $87 \%$ мањи у односу на јануар претходне године. (UNWTO - News Release, 2021). Колапс међународних путовања представља процењени губитак од прихода од извоза од 1,3 милијарде USD - више од 11 пута више од губитка забележеног током глобалне економске кризе 2009. године. (UNWTO - News Release, 2021).

Када је у питању туристичку сектор у Републици Србији, тренд раста ноћења страних туриста, започет почетком 2000. године, није се наставио 2020. године због пандемије изазване коронавирусом. У периоду јануар-септембар остварено је око 970 хиљада ноћења, што је 68\% у односу на исти период прошле године. Након изузетно лоших резултата у другом тромесечју 2020. године, када је број ноћења страних туриста у односу на исти период 2019. године био мањи за $91,1 \%$, у трећем кварталу број ноћења страних туриста био је нешто већи ( 241.565), што је за $82,1 \%$ мање него у истом периоду 2019. (Anufrijev, Dašić, 2021)

Табела 2 - Квартални индекси ноћења туриста (\%) / Table 2 - Overnight stay of tourists quarterly indices (\%)

\begin{tabular}{|c|c|c|c|c|c|c|c|c|c|}
\hline & 2018 & \multicolumn{4}{|c|}{2019} & \multicolumn{4}{c|}{2020} \\
\cline { 2 - 11 } & Укупно & Q1 & Q2 & Q3 & Q4 & Q1 & Q2 & Q3 & Q4 \\
\hline Укупно & 447.7 & 103.9 & 107.2 & 105.6 & 116.6 & 98.3 & 28.1 & 74.9 & 52.8 \\
\hline Домаћи туристи & 439.7 & 101.3 & 107.6 & 105.4 & 113.6 & 101.5 & 39.3 & 113.0 & 71,1 \\
\hline Страни туристи & 458.9 & 108.3 & 106.4 & 105.8 & 120.6 & 93.2 & 8.9 & 17.9 & 30.2 \\
\hline
\end{tabular}

Извор / Source: (Р33С, 2021)

Кризе представљају стресан период и за друштво и за привреду. Различити су ставови по питању тога како кризе утичу на туризам као привредну делатност, односно њен опоравак. Постоји мишљења да је туристички сектор прилично отпоран на утицаје криза у смислу да се лако прилагођава и релативно брзо опоравља, односно враћа на предкризни период, У прилог таквом ставу наводи се података да је Светска фринансијска криза 2007-2008. године утицала на туристички сектор само 2009. године, када је забалежен мањи број туриста на глобалном нивоу и значајан пад туристичког промета. Већ следеће, 2010. године забележен је раст.

Међутим, Светска фринансијска криза 2007. године не може да се пореди са кризом која је изазвана пандемијом COVID-19. Док је изрок наведене криза био искључиво економско финансијски, пандемија COVID-19 је превасходно здравствена криза чије су импликације економска и друштвена криза. У Табели 3. три дат је приказ пандемија које су се јавиле у прериоду после II Светског рата.

Прве случајеве COVID-19, болести изазване коронавирусом SARS-CoV-2, пријавили су званичници у кинеском граду Вухан у децембру 2019 године. Већина првих пријављених случајева имала је везе са отвореном пијацом хране у Вухану, јер су међу оболелима углавном били власници тезги, запослени на пијаци или редовни посетиоци ове пијаце. Узорци узети са ове пијаце у децембру 2019. године били су позитивни на SARS-CoV-2, што указује да је пијаца у граду Вухан извор избијања пандемије или да је имала значајну улогу у њеној ескалацији.

Светска здравствена организација је 11. марта 2020. прогласила ширење новог коронавируса глобалном пандемијом (COVID-19). Одлука је донета након што је утврђено да се за само две недеље број случајева ван Кине повећао 13 пута, а број земаља које су регистровале присуство вируса три пута. У циљу сузбијање даљег ширења вируса већина држава је почела са увођењом мера које су обухватале ограничење и забрану кретања, затварање граница и сл. Тринаест месеци након проглашења пандемије, 12.04.2021, према подацима Светске здравствене организације забележено је 135.646.617 потврђених случајева COVID-19, од чега 2.930.732 са смртним исходом. (WHO Coronavirus (COVID-19) Dashboard, 2021). 
Табела 3 - Преглед неких од пандемија у свету после II Светског рата /

Table 3 - An overview of some of the pandemics in the world after World War II

\begin{tabular}{|c|c|}
\hline $\begin{array}{c}\text { Врста } \\
\text { пандемије }\end{array}$ & Карактеристике пандемије \\
\hline $\begin{array}{c}\text { Азијски грип } \\
\text { (Х2H2) }\end{array}$ & $\begin{array}{l}\text { Азијски грип потекао је из кинеске провинције Јунан почетком 1957. До августа исте } \\
\text { године болест се прошириа на већи део света, а врхунац је био крајем године. } \\
\text { Ззахватио је углавном децу школског узраста, омладину и труднице. Врхунац другог } \\
\text { таласа био је годину дана касније, када је било захваћено више подручја, укључујући } \\
\text { Европу, Северну Америку и Јапан, и за разлику од првог овога пута је била погођена } \\
\text { старија популација. Не постоји прецизни подаци, али је процењено да је умрло } 1,1 \\
\text { милион људи широм света. Стопа смртности је била } 1 \text { на } 4000 \text { или } 0.025 \% \text {. } \\
\text { Националне процене смрти нису широко доступне, али у САД су износиле између } \\
80.000 \text { и 110.000; у Енглеској и Велсу процењује се да износи око } 6.000 .\end{array}$ \\
\hline $\begin{array}{l}\text { Хонгконшки } \\
\text { грип (Х3Н2) }\end{array}$ & $\begin{array}{l}\text { Хонгконшки грип је први пут забележен у Хонг Конгу 13. јула 1968. године. У првих } \\
\text { шест месеци било је заражено } 500.000 \text { становника Хонг Конга или } 15 \% \text { укупне } \\
\text { популације. До краја јула вирус се проширио на Вијетнам, Сингапур, да септембра } \\
\text { болест се проширила и на Индију, Филипине, Аустралије и Европу. У САД први } \\
\text { случајеви су забележени у Калифорнији, а донели су га амрички војници који су се } \\
\text { враћали уз из Вијетнамског рата. Према подацима Центра за контролу болести и } \\
\text { превенцију, од вируса ХЗН2 умрло је око милион људи широм света, углавном } \\
\text { старијих старијих од } 65 \text { година. }\end{array}$ \\
\hline $\begin{array}{c}\text { Птичји грип } \\
\text { (X1H1) }\end{array}$ & $\begin{array}{l}\text { 2009. године појавио се нови пандемијски грип - први после } 40 \text { година. Први случај } \\
\text { откривен је у Калифорнији у априлу 2009; Светска здравствена организација (СЗО) } \\
\text { прогласила је крај пандемије у августу 2010. године. Само неколико дана после } \\
\text { првог случаја у Калифорнији, у Мексику су регистровани нови случајеви. Два дана } \\
\text { касније у Шпанији и Великој Британији пријављени су први случајеви што су уједно } \\
\text { били и први случајеви у Европи. Генерални директор СЗО објавио је светску } \\
\text { пандемију 11. јуна 2009. године, отприлике два месеца након првог случаја. Центар } \\
\text { за контролу болести и превенцију процењује да је између } 151.700 \text { и } 575.400 \text { људи } \\
\text { умрло широм света (0,001-0,007\% светске популације). Највећи број случајева } \\
\text { забележен је у САД, Мексику, Канади и Великој Британији. Највише умрлох је било } \\
\text { у Мексику и САД. }\end{array}$ \\
\hline $\begin{array}{c}\text { Тешки акутни } \\
\text { респираторни } \\
\text { синдром } \\
\text { (СAPC) }\end{array}$ & $\begin{array}{l}\text { САРС је вирусна болест коју је изазвао САРС коронавирус крајем 2002. године у } \\
\text { Кини; СЗО је о епидемији обавештена у фебруару 2003. године До краја марта } 2003 . \\
\text { године широм света је пријављено } 210 \text { сумњивих и вероватних случајева САРС-а. } \\
\text { Између новембра 2002. и јула 2003. године пријављено је } 8.096 \text { случајева, од тога } \\
774 \text { са смртним исходом. САРС је имао високу стопу смртности од 9,6\%, али је био } \\
\text { далеко мање заразан од претходних пандемија. Највише случајева било је у Кини } \\
\text { (5.327) и Хонг Конгу (1.755), где су стопе смртности износиле } 7 \% \text {, односно } 17 \% \text {; }\end{array}$ \\
\hline $\begin{array}{c}\text { Блискоисточни } \\
\text { респираторни } \\
\text { синдром } \\
\text { (MEPC) }\end{array}$ & $\begin{array}{l}\text { МЕРС је вирусна респираторна болест узрокована коронавирусом (МЕРС - ЦоВ) } \\
\text { која је пронађена у дромедар камилама у неколико земаља. Прво случајеви } \\
\text { идентификовани су у Саудијској Арабији 2012. године, а затим се проширило на } 27 \\
\text { земаља: Блиског истока, Европе, САД, Севера Африке, Југоисточне Азије. Међутим, } \\
\text { био је високо концентрисан у Саудијској Арабији (више од } 80 \% \text { случајева). Сви } \\
\text { случајеви идентификовани ван Блиског истока били су код људи који су се заразили } \\
\text { на Блиском истоку. Болест је врло смртоносна, а СЗО процењује да је око } 35 \% \\
\text { пријављених пацијената умрло. }\end{array}$ \\
\hline $\begin{array}{c}\text { Вирусна } \\
\text { болест ебола } \\
\text { (ЕВД) }\end{array}$ & $\begin{array}{l}\text { ЕВД је фратална болест код људи, са просечном стопом смртности од око } 50 \% \text { (у } \\
\text { распону од } 25 \% \text { до 90\% према таласима избијања; за детаље видети ВХО.инт). } \\
\text { Прво избијање је идентификовано 1976. године у Демократској Републици Конго и } \\
\text { Судану, где је стопа смртности износила } 88 \% \text {, односно } 53 \% \text {, са приближно } 300 \\
\text { случајева у обе државе. Други талас је био у 2014-2016. Години, започињући у } \\
\text { западној Африци, и био је највећи од свог открића 1976. године и у погледу } \\
\text { случајева и смртних случајева. }\end{array}$ \\
\hline
\end{tabular}

Извор / Source: Прилагођено / Adapted (Baldwin, Weder di Mauro, 2020)

На основу члана 200. став 5. Устава Републике Србије, председник Републике, председник Народне скупштине и председник Владе донели су Одлуку о проглашењу ванредног стања због ширења корона вируса. Народна скупштина Републике Србије укинула је ванредно стање 6. 
маја 2020. године, али су одређене мере остале на снази. До 12.04.2021. године у Републици Србији забележено је 645,173 регистрованих случајева, 5,773 смртних случајева, а проценат смртности износио је 0.89\%. (https://covid19.rs/, 2021).

Осим узрока, актуелна пандемије COVID-19 скоро да нема сличности са ранијим епидемијама и пандемијама које су наведене у Табели 3. Из наведене табеле се лако може уочити да су раније епидемије и пандемије имале су или мањи обухват, мању смртност, или су брже сузбијене.

Екотуризам управо представља начин да човек своје потребе за путовањем задовољи на начин који није погубан по животну средину. Настаоје као потреба за бегством из града, пражњење од стреса, повратак мајци природи из солитера и густих насеља, за туризмологе представља једну посебну грану туризма која захтева нов холистички маркетинг, а у предузетничком смислу нов концепт пословања еко домаћинстава у којима треба понудити поред природних лепота и гастро производе са географским пореклом, народну традицију, културу и схватања из локалног амбијента (Дашић, Ануфријев, 2018). Међународно друштво за екотуризам (engl. The International Ecotourism Society - TIES) је највећа и најстарија организација за екотуризам на свету посвећена промоцији и ширењу информација о екотуризму и одрживом туризму, одговорним путовањима у природна подручја која чувају животну средину, одржавају добробит локалног становништва и укључују тумачење и образовање (TIES, 2015).

Развој екотуризам се поклапа са развојем еколошког покрета током 70-их и 80-их година XX века. Растућа забринутост за животну средину, заједно са растућим незадовољством масовним туризмом довела је до повећане потражње за природним искуствима алтернативне природе. Почев од 1990-их, екотуризам расте 20\% - 34\% годишње. 2004. године. Екотуризам / туризам у природи растао је глобално 3 пута брже од туристичке индустрије у целини (TIES, 2006). Према Међународном друштву за екотуризам, 83\% земаља у развоју ослања се на приходе од екотуризма, док се неке, попут Костарике, Еквадора, Непала, Кеније, Мадагаскара и Антарктика, ослањају на приходе од екотуризма као главни фрактор који доприноси њиховом развоју, генерисању бруто домаћег производа и запослености.

Туристички промет у сегменту екотуризма у 2019. години процењен је на 181,1 милијарду долара, а очекује се да ће достићи 333,8 милијарди долара до 2027. године, по сложеној годишњој стопи раста од 14,3\% од 2021. до 2027. године. Сегмент групног туризма предњачио је у погледу удела на тржишту екотуризма у 2019. години и очекује се да задржи доминацију и у наредном периоду. (Allied Market Research, 2020).

На жалост, ескалације пандемије COVID -19 учинила је да очекивања из претходне године остану мртво слово на папиру. Колико год је садашњи тренутак тежак, а будућност неизвесна, ови ситуацију треба да посматрамо као изазов из којег треба извучемо одређене поуке. По неким ауторима, еволуција туризма је увек била делимична (нпр. екотуризам се често развија на подручјима масовног туризма). COVID-19 пружа прилику једном у генерацији да се уради трансформација. (Benjamin, et al., 2020). Другим речима, пандемију треба искористи да се направе дугорочне структурне промене у туристичком сектору које би га приближиле принципима екотуризма, односно да се направи отклон од свега онога што је било лоше и неодрживо у туризму. Иако је криза још у току и тешко је предвидети њен даљи ток и завршетак, постковид развој екотуризма морао би да обухвати:

- $\quad$ климатске промене и одрживи развој

- подршку јавних институција,

- промена у понашању потрошача,

- домаће туристе

- интересе стејкхолдера,

- примену технолошких иновација - дигитализације,

- припаднике локалне заједнице.

Климатске промене представљају претњу за целокупно човечанство. Климатске промене представљају изазов са којим се компаније широм света данас суочавају и намећу потребу да се редифинишу сви сегменти пословања, како би адаптирале своје пословање не само новонасталој ситуацији, већ и свим будућим променама које се већ сада могу предвидети (Дашић и др., 2020). Екотуризам је посебно осетљив, пошто се базира природним локалитетима и атракацијама на које је утицај климатских промена најизраженији. На жалост, климатске промене су иреверзибилан процес, али оно што може да се уради на пољу туризма је са се развију одрживи модели екотуризма који би били у функцији успорења климатских промена. Пандемија COVID-19 представља изазов глобалном захтеву за постизањем Агенде одрживог развоја до 2030. године, са својих 17 повезаних циљева развоја (Nhamo, et al., 2020). Агенда одрживог развоја до 2030. године представља споразум свестских лидера у Уједињеним нацијама који је потписан 2015. 
године. Потипсници споразума су се обавезали да следе 17 циљева одрживог развоја који би довели до боље будућности за све. Заправо, то је глобални оквир за заустављање крајњег сиромаштва, борбу против неједнакости и неправде и поправљање климатских промена до 2030. године. Туризам има потенцијал да директно или индиректно допринесе овим циљевима. Посебно је укључен у циљеве 8, 12 и 14 о инклузивном и одрживом економском расту, одрживој потрошњи и производњи (СЦП), односно одрживој употреби океана и морских ресурса.

Подршка јавих институција превасходно треба да се односи на помоћ туристичком сектору да се прилагоди на новонасталу ситуацију и трансформише у правцу одрживог развоја. Та подршка треба да се огледа у креирању институционалног оквира и различитим пакетима фринансијске помоћи који би били у функцији очувања биодиверзитетра и посебности туристичких дестинација од девастације коју проузрокује индустријски развој, али и масовни туризам. Другим речима, улога владе у овом контексту би била проналажење идеалног односа између економског интереса и егзистенције становништва и очувања животне средине. То заправо значи да друштвено благостање треба да се посматра у најширем смислу те речи, као спој материјалног, али и духовног и здравственог.

Пандемија COVID-19 је од здравствене кризе врло брзо постала економска и социјална криза. Људи широм света су били приморани да промене своје свакодневне навике како због донетих мера, тако и због забринутости за сопствено здравље и егзистенцију. Велика је вероватноћа да ће два наведена фактора: здравље и егзистенција бити доминантни критеријуми приликом доношења различитих одлука потрошача у будућности, укључујући ту и одлуке за избор врсте одмора (путовања) и туристичке дестинације. Потенцијални туристи приликом одабира туристичке дестинације водиће рачуна о епидемиолошкој ситуацији, санитарним и хигијенским условима, здравственом систему и сл. Наравно, не сме се занемарити то да ће и у будућности понашање потрошача бити под утуцајем „класичних“ фрактора као што су технологија, иновације, животни стандард, социјални статус и др.

Фокус на домаће туристе, на неки начин, произилази из промена у понашању потрошача. Забринутост за здравље и неизвесност по питању материјалне егзистенције код потенцијалних туриста може да резултира фраворизање домаћих дестинација. Мањи трошкови, близина куће, мањи ризик и неизвесност у случају нежељеног догађаја, боравак у природи, дистанцирање од гужве, само су неки од разлога да туристи одаберу одређену домаћу дестинацију. То само значи да пружаоци туристичких услуга приликом дизајнирања својих понуда имају у виду посебне захтеве туриста у погледу тих захтева.

Стејкхолдери представљају значајну групацију за остваривање одрживог развоја кроз развој екотуризма. Као и било ком другом пословном или туристичком сектору, тако и екотуризму сарадња између различитих стејкхолдера представља прави изазов због међусобно супростављених циљева и интереса који се могу свести на супротстављеност краткорочног интереса - профита и дугорочног циља - очувања биодиверзитета и дестинације екотуризма. Генерално, ефикасна сарадња заинтересованих страна резултира следећим (Wondirad, et al., 2020):

- омогућавање одрживог развоја екотуризма кроз усклађивање планова екотуризма са другим програмима економског развоја;

- осмишљавање свеобухватних решења;

- побољшање изводљивости планова;

- промовисање дискусија, комуникација и преговора међу актерима екотуризма и

- јачање поверења и узајамног разумевања међу заинтересованим странама.

Кризне ситуације утичу на омасовљење примене нових технологија како у пословне, тако и у личне сврхе. Роботи, аутоматизација производних процеса и примена вештачка интелигенције, основа су Индустријске револуција 4.0, смањују трошкове, побољшају ликвидност и повећавају флексибилност. (Sharma et al., 2021). Слично томе, у јеку најстрожих мера у борби против COVID-19, технологија је била та која је омогућила људима да комуницирају, купују и повежу се поштујући мере социјалне дистанце. Данашње информатичко друштво је изграђено на технологији, знању и интелигенцији. Информацине технологије омогућавају лакши и бржи проток знања и информација до људи, чија адекватна употреба може значајно допринети остваривању одрживог раста и развоја (Јанковић и др., 2020).

У сегменту екотуризма нове технологије омогућују креирање виртуелних тура, које су у време пандемија или других кризних ситуација, свима онима који нису у могућности из неког разлога да путују, начин да им се приближе одређене егзотичне дестинације. Интерактивни садржај не само да приближава одређену дестинацију потенцијалним путницима, већ и на одређени начин и едукује. Увођењем садржаја који се посебно 
плаћају или остављањем могућности донација, прикупљају се сртедства која могу бити од користи дестинацијама екотуризма које су посебно погођене пандемијом.

Екотуризам има потенцијал да економски, социјално, политички и инфраструктурно унапреди локалну заједницу, односно живот локалног становништва. У том погледу неопходно је пронаћи баланс између принципа екотуризма и развојних планова локалне заједнице. У постковид периоду мора да се води рачуна да циљеви економског развоја, односно масовног туризма не добију примат у односу на екотуризам.

\section{ЗАКЉУЧАК / CONCLUSION}

Пандемија COVID-19 суочила је свет са невиђеном глобалном здравственом кризом која има драматичан утицај на друштво и његову егзистенцију. На удару мера предузетих за спречавање ширења пандемије нашли су се скоро све привредне гране, а туризам спада у највише погођене. Још увек је рано да се говори о последицама кризе, јер се још увек не назире њен крај и даљи ток, али оно што се са сигурношћу сада може утврдити јесте да ће трајно променити свет који смо знали. Међутим већ сада се могу специфрицирати одређени фрактори који ће играти главну улогу у обликовању туризма, а нарочито екотуризма у пост кризном периоду. Колико год нереално звучало, ову кризу треба посматрати као паузу, „тајмаут“ који треба да послужи за преиспитавање досададашње туристичке политике и идентифоковање свега негативног што је одликовало туризам пре кризе, па на основу тог приступити структурним променама и проналажењу модела који ће да омогуће развој одрживог и екотуризма.

Екотуризам је посебно осетљиво подручје, чији развој у посткризном периоду мора да буде пажљњиво планиран и спровођен. Екотуризам је и пре ове кризе био под притиском развоја масовног туризма, односно профитних циљева. После кризе тај притисак ће да буде још већи, јер ће економска и егзистенцијална питања да буду приоритет. У том погледу потребно је пажљиво анализирати и пратити промене сваког у раду наведеног фактора за развој екотуризма у постковид периоду, како би се осигурао несметан развој екотуризма. Полазне тачке приликом формулисања било које стратегије екотуризма треба да буду Принципи екотуризма, Међународно друштво за екотуризам и Агенда одрживог развоја до 2030. године Уједињених Нација.

\section{ЛИТЕРАТУPA / REFERENCES}

[1] Allied Market Research, (2020), Opširnije na https://www.alliedmarketresearch.com/ecotourism-market-A06364

[2] Anufrijev, A, Dašić, G. (2021). Risk of Health Tourism and Rehabilitation Segment in Serbia During The COVID-19 Pandemic, FBIM Transactions, Vol 9, No 1.

[3] Baldwin, R., Weder di Mauro, B. (2020). Introduction in Economics in the Time of COVID-19, Edited by Richard Baldwin, R. and Weder di Mauro, B., London: CBR Press.

[4] Benjamin, S., Dillette, A. \& D. H. Alderman (2020), "We can't return to normal": committing to tourism equity in the post-pandemic age, Tourism Geographies, 22(3), 476-483,

DOI:10.1080/14616688.2020.1759130

[5] Dašić, G., Popov-Locke, J., Đervida, R., Radosavac, A. (2020). Zaštita životne sredine u Industriji 4.0 - potencijal korporativne društvene odgovornosti, Ecologica, 27(98), pp. 319-325.

[6] Dašić, G., Anufrijev, A. (2018). Determinante unapređenja i strategije razvoja i promocije zelene ekonomije u okvirima ekoturizma, Ecologica, 25 (92), 805-811.

[7] Janković, M., Jovanović, L., Krasulja, N. (2020). Značaj informacionih tehnologija u formiranju modela održivog razvoja, Ecologica, 27(98), 319-325.

[8] Khan, A., Bibi, S., Lorenzo, A., Lyu, J., Babar Z.U. (2020). Tourism and Development in Developing Economies: A Policy Implication Perspective, Sustainability, 12, 1618; doi:10.3390/su12041618

[9] Nhamo, G., Dube, K., Chikodzi, D. (2020). Counting the Cost of COVID-19 on the Global Tourism Industry, Cham: Springer.

[10] Republički zavod za statistiku - RZZS (2021), Trendovi.

[11] Sharma, G.D., Thomas, A., Paul, J. (2021). Reviving tourism industry post-COVID-19: A resilience-based framework, Tourism Management Perspectives, 2021 Jan; 37: 100786.

[12] The International Ecotourism Society -TIES (2006), TIES Global Ecotourism Fact Sheet, Washington, DC

[13] The International Ecotourism Society -TIES (2015), https://ecotourism.org/

[14] UNWTO (2021). Tourist Arrivals Down 87\% in January 2021 as UNWTO calls for Stronger Coordination to Restart Tourism, News Release, Madrid, 31 March 2021.

[15] UNWTO (2021). World Tourism Barometer Excerpt, Volume 19, Issue 1. January 2021.

[16] UNWTO (2021). 2020: Worst Year in Tourism History with 1 Billion Fewer International Arrivals, News Release, Madrid, 28 January 2021. 
[17] UNWTO (2020). International Tourist Numbers Could Fall $60-80 \%$ in 2020, UNWTO Reports, News Release, Madrid, 07 May 2020

[18] UNWTO (2020). World Tourism Barometer Excerpt, Volume 18, Issue 1. January 2020.

[19] UNWTO (2020). UNWTO Tourism Highlights, 2020 Edition

[20] UNWTO (2019). UNWTO Tourism Highlights, 2019 Edition

[21] UNWTO (2018). UNWTO Tourism Highlights, 2018 Edition
[22] UNWTO (2017). UNWTO Tourism Highlights, 2017 Edition

[23] UNWTO (2016). UNWTO Tourism Highlights, 2016 Edition

[24] Wondirad, A., Tolkach, D., King, B. (2020). Stakeholder collaboration as a major factor for sustainable ecotourism development in developing countries, Tourism Management, Vol. 78, June 2020.

[25] https://covid19.rs/

[26] https://covid19.who.int/. 